\title{
Червона книга
}

\section{С.Л. МОСЯКІН}

Інститут ботаніки імені М.Г. Холодного НАН України

вул. Терещенківська, 2, м. Київ, МПС-1, 01601, Україна

\section{НОМЕНКЛАТУРНО-ТАКСОНОМІЧНІ ЗМІНИ, ЩО СТОСУЮТЬСЯ ДЕЯКИХ ВИДІВ СУДИННИХ РОСЛИН, ЗАНЕСЕНИХ ДО «ЧЕРВОНОЇ КНИГИ УКРАЇНИ»}

Ключові слова: таксономія, номенклатура, судинні рослини, Червона книга України, Paragymnopteris, Colchicum, Crocus, Gagea, Rhaponticoides, Kalmia, Clinopodium, Phlomoides, Torminalis

Цілком очевидно, що послідовне відображення молекулярно-філогенетичних результатів у номенклатурі та суворе дотримання принципу монофілії (голофілії) таксонів найближчим часом може спричинити широкомасштабні зміни звичних наукових назв судинних рослин, у тому числі на видовому та родовому рівнях. За деякими оцінками (Vorontsova, Simon, 2012), для родини Роасеае кількість таких змін може сягнути від 10 до $20 \%$ загальної кількості всіх нині прийнятих видових назв.

Зрозуміло, що зміни звичних назв можуть викликати незадоволення тих науковців, і не лише науковців, які стикаються з назвами рослин у своїй повсякденній практиці й зацікавлені у стабільності номенклатури. Проте запобігти цьому в більшості випадків неможливо. Таксономічні зміни можуть опосередковано впливати і на практику охорони рослин, а також на різні аспекти їхнього використання (Stace, 2010).

Особливе значення для практичних цілей охорони видів рослин України мають номенклатурнотаксономічні зміни на видовому рівні, які стосуються таксонів, занесених до «Червоної книги УКраїни» (2009). Як відомо, ця книга є державним документом, котрий містить відомості саме про види та деякі інші таксони, що підлягають охороні на за-

(С) С.Л. МОСЯКІН, 2013 гальнодержавному рівні, тому чітке визначення та недвозначне і стабільне найменування таких таксонів $є$ важливим і з юридичної точки зору. Ми можемо зіткнутися з ситуаціями, коли таксономічна чи номенклатурна невизначеність може призвести до спроб вивести з-під охорони певні таксони, оскільки їхні синонімічні, альтернативні чи прийняті назви не згадуються в «Червоній книзі України», або ж ці таксони деякими авторами розглядаються як синоніми інших таксонів, або ж як окремі види, котрі на даний момент не включені до «Червоної книги України». Щоб уникнути таких ситуацій, варто розробити зміни до Закону України «Про Червону книгу України», які б убезпечили взяті під охорону види й таксони інших рангів від їх виведення 3-під охорони з причин суто номенклатурних змін їхніх назв або таксономічного трактування обсягу виду тощо. Проте до внесення змін до законодавства актуальним завданням систематиків $є$ відстеження всіх відповідних номенклатурно-таксономічних новацій, реєстрація нових назв (у тому числі синонімів) і обгрунтування прийняття або відхилення тих чи інших запропонованих номенклатурно-таксономічних рішень, що стосуються видів, включених до «Червоної книги України».

Саме $з$ такою метою ми розглядаємо тут деякі номенклатурно-таксономічні зміни, переважно на родовому та почасти видовому рівнях, які виплива- 
ють із результатів недавніх молекулярно-філогенетичних і таксономічних досліджень і безпосередньо стосуються видів судинних рослин, занесених до третього видання «Червоної книги України» (2009). До таких змін насамперед належать: 1) перенесення видів з одного роду до іншого, 2) розширення обсягу певних родів або, навпаки, 3) розділення філогенетично неприродних (поліфілетичних або парафілетичних) родів на сегрегатні монофілетичні роди, 4) виявлені випадки номенклатурної нелегітимності (незаконності) певних назв тощо.

Звичайно ж, у сучасній філогенетичній систематиці відбуваються зміни й на рівні родин судинних рослин, і на інших рівнях, але ми розглянемо їх згодом в окремій статті.

Види в тексті статті розміщені по родинах, а самі родини наводяться за алфавітом за основними підрозділами - відділами (Pteridophyta та Magnoliophyta) та класами покритонасінних (Liliopsida та Magnoliopsida у традиційному розумінні), тобто так, як вони розміщені в третьому виданні «Червоної книги України» (2009). Для кожного таксона, крім прийнятої назви, наводяться основні синоніми з відповідними номенклатурними цитаціями, а також посилання на літературні джерела та обговорення. Особлива увага приділена тим таксонам, нові назви яких і відповідна синоніміка не були наведені в номенклатурному конспекті судинних рослин УКраїни (Mosyakin, Fedoronchuk, 1999) та інших вітчизняних джерелах.

\section{Pteridophyta}

Родина Sinopteridaceae Koidz. (Pteridaceae s.l.)

Paragymnopteris K.H. Shing, 1993 (publ. 1994), Indian Fern J. 10(1-2): 227.

Paragymnopteris marantae (L.) K.H. Shing, 1993 (publ. 1994), Indian Fern J. 10(1-2): 229.

- Acrostichum marantae L., 1753, Sp. Pl. 2: 1071.

- Ceterach marantae (L.) DC. in DC. \& Lam., 1805, Fl. Franc., ed. 3, 2: 567.

- Cincinalis marantae (L.) Desv., 1811, Berl. Mag. 5: 312. - Gymnogramma marantae (L.) Mett., 1856, Fil. Hort. Bot. Lips.: 43.

- Notholaena marantae (L.) Desv. 1813, Journ. Bot. appl. 1: 92. 1813. (R.Br., 1810, Prodr. Fl. N. Holl.: 146. 1810, nom. inval.)

- Paraceterach marantae (L.) R.M. Tryon, 1986, Amer. Fern J., 76(4): 186.

У «Червоній книзі України» (2009) цей вид наведений під назвою Notholaena marantae 3 автор- ством «(L.) Desv.». У деяких джерелах автором видової комбінації вважається Р. Браун, який встановив рід Notholaena (Brown, 1810). Проте при першоописі роду він навів з описами три види з Австралії, а в примітці до роду лише згадав два інші види як такі, що, на його думку, також сюди належать: «Нuc, praeter sequentes Novae Hollandiae, pertinent Acroctichum Marantae, Pteris trichomanoides L. et aliae nonnulae ineditae». Ця обставина й дотепер спричиняє певні проблеми для типіфікації роду Notholaena.

Принаймні три лектотипи вживалися у практиці систематики роду: Notholaena trichomanoides (L.) Desv. (= Pteris trichomanoides L.), N. marantae та N. distans R. Вr. Найдетальніше історію та сучасний стан цього питання висвітили Дж. Яцкевич і А.P. Сміт (Yatskievych, Smith, 2003). Нині американські (Windham, 1993; Yatskievych, Smith, 2003) та російські (Шмаков, 2001; Цвелев, 2005) вчені, а також молекулярні філогенетики (Rothfels et al., 2008) надають перевагу лектотипіфікації роду Notholaena американським (карибським) видом $N$. trichomanoides, а європейські птеридологи за лектотип визнають переважно вид N. marantae (Pichi Sermolli, 1989; FraserJenkins, Dulawat, 2009; García-Barriuso et al., 2011). B останньому випадку більшість американських представників групи мають розглядатися в роді Chrysochosma (J. Sm.) Kümmerle, а австралійських - у роді Paraceterach Copel., або ж бути розділеними по інших сегрегатних родах. Раніше (до підтвердження поліфілії Notholaena s. 1.) цю проблему конфліктної лектотипіфікації можна було формально оминути, визнаючи Notholaena в широкому сенсі, проте тепер ситуація кардинально змінилася.

Види та роди з групи так званих «хейлантоїдних» папоротей різні автори відносили до родин Sinopteridaceae Koidz. (s. str.), Negripteridaceae Pichi Serm., Cheilanthaceae B.K. Nayar та Hemionitidaceae Pichi Serm., проте нині переважає тенденція надавати цій групі ранг підродини, Pteridaceae E.D.M. Kirchn. subfam. Cheilanthoideae W.C. Shieh (див. Мосякін, Тищенко, 2010; Smith et al., 2006; Christenhusz et al., 2011). У ранзі родини для всієї цієї групи прийнятною є назва Sinopteridaceae. У цій групі є види, які демонструють морфологічні пристосування до існування в посушливих умовах середовища. До таких належать також види, які традиційно відносили до роду Notholaena. Водночас багато птеридологівщедо отримання перших надійних молекулярнофілогенетичних результатів (Gastony, Rollo, 1995) вважали, що цей рід у його традиційному розумінні 
є поліфілетичним і потребує розділення на декілька більш природних родів. Такі припущення виявилися слушними.

Як стало тепер зрозуміло завдяки молекулярнофілогенетичним дослідженням (Rothfels et al., 2008; Windham et al., 2009), подібні морфологічні адаптації до аридних умов є конвергентними; вони незалежно й неодноразово виникали в різних кладах хейлантоїдних папоротей. Абсолютна більшість видів, які відносили до Notholaena, належить до переважно американської клади, котра містить і перший законно обраний лектотип роду $-N$. trichomanoides, тимчасом як інші, запропоновані пізніше, лектотипи належать до двох значно віддалених одна від одної та від Notholaena s. str. клад: $N$. distans до клади «hemionitidoids» («геміонітидоїдні папороті»), а N. marantae - до «pellaeoids» («пеллеоїдні папороті»). Єдиним задовільним і остаточним рішенням була б номенклатурна консервація родової назви Notholaena із законсервованим типом, причому малоймовірно, що цим типом визнають $N$. marantae. Нині різні автори продовжують використовувати дві альтернативні лектотипіфікації, але ваги схиляються на користь $N$. trichomanoides, який є найчастіше вживаним лектотипом (так званий «standing type»). Зважаючи на вищевикладене, єдиний вид флори України, який відносили до Notholaena, тепер має бути переведений до роду Paragymnopteris.

\section{Magnoliophyta: Liliopsida}

Родина Colchicaceae DC.

Colchicum versicolor Ker. Gawl., 1821, Bot. Reg. 7: t. 571 .

- Bulbocodium vernum L. subsp. versicolor (Ker Gawl.) K. Richt., Pl. Eur. 1: 189 (1890).

- Bulbocodium versicolor (Ker. Gawl.) Spreng., 1825, Syst. Veg. 2: 40.

- Colchicum bulbocodium Ker Gawl. subsp. versicolor (Ker Gawl.) K. Perss., 2007, Bot. Jahrb. Syst. 127: 178.

- Colchicum bulbocodium Ker Gawl. var. versicolor (Ker Gawl.) K. Perss., 2007, Bot. Jahrb. Syst. 127: 178. У «Червоній книзі України» (2009) цей вид наведено як Bulbocodium versicolor. Сучасні автори молекулярно-філогенетичних публікацій (Vinnersten, Reeves, 2003; Manning et al., 2007; Vinnersten, Manning, 2007; Persson et al., 2011) підтримують об'єднання родів Bulbocodium L., Colchicum L. s. str., Merendera Ramond, Androcymbium Willd. та деяких інших у роді Colchicum sensu lato. В такому випадку, за умови визнання видового статусу центрально- i східноєвропейських та західноазійських рослин, правильною назвою для нашого виду буде Colchicum versicolor Ker Gawl.

Проте слід зазначити, що цей вид (у широкому розумінні) був описаний К. Ліннеєм як Bulbocodium vernum L., і лише згодом з його складу виділили декілька таксонів видового або внутрішньовидових рангів (див. наведену синоніміку). Тепер монограф роду (Persson, 2007), а також і укладачі World Checklist of Selected Plant Families (Royal Botanic Gardens, Kew, United Kingdom: http://apps. kew.org/wcsp, станом на жовтень 2012 р.) вважають, що вид $C$. bulbocodium представлений двома підвидами: subsp. bulbocodium (поширений від Піренеїв, Альп і приальпійських регіонів до півдня Австріi) та subsp. versicolor (Ker Gawl.) K. Perss. (поширений далі на схід і південний схід від ареалу номінативного підвиду). Крім того, $C$. bulbocodium var. edentatum (Schur) K. Perss. (2007, Bot. Jahrb. Syst. 127: 179) вважається різновидом, ендемічним для Румунії. За умови широкого розуміння C. bulbocodium і визнання підвидового статусу поширених в Україні рослин, правильною (або альтернативною) назвою для включеного до «Червоної книги України» виду буде C. bulbocodium Ker Gawl. subsp. versicolor (Ker Gawl.) K. Perss.

Для довідки нижче наводимо синоніміку Colchicum bulbocodium у широкому розумінні.

Colchicum bulbocodium Ker Gawl., 1807, Bot. Mag. 26: t. 1028, p.p.

- Bulbocodium vernum L., 1753, Sp. Pl.: 294, p.p.

- Merendera verna (L.) Bubani, 1902, Fl. Pyren. 4: 137.

- Colchicum vernum (L.) Stef., 1926, Сборн. Българ. Акад. наук 22: 48, nom. illeg., non (Reichard) Georgi, 1800, Beschr. Russ. Reich. 3(4): 923.

\section{Iridaceae Juss.}

Crocus tauricus (Trautv.) Puring, 1900, Труды Бот. сада Имп. Юрьевского унив. (Trudy Bot. Sada Imp. Yur'evsk. Univ.) 1: 194.

- Crocus biflorus M.Bieb. var. tauricus Trautv., 1859, Bull. Cl. Phys.-Math. Acad. Imp. Sci. Saint-Pétersbourg 17: 329.

У попередньому звіті (на правах рукопису, 2011 р.) стосовно видів, занесених до «Червоної книги УКраїни», ми (автор - С.Л. Мосякін) зазначали, що з назвою Crocus tauricus (Trautv.) Puring пов'язані серйозні таксономічні та номенклатурні проблеми на 
видовому та внутрішньовидовому рівнях, які впливають на охоронний статус цього таксона. Тоді вбачалося, що назва, під якою вид був наведений у третьому виданні «Червоної книги України» (2009), є незаконною (молодший омонім раніше опублікованої назви) і через те не може використовуватися, а тому попередньо була запропонована нова назва (Crocus neotauricus Mosyakin, nom. nov. provis.). Ми також зазначали, що до їі валідизації потрібні додаткові номенклатурні та таксономічні розвідки.

Такі номенклатурні дослідження були проведені останнім часом із залученням протологів (першоописів) критичних таксонів, які були отримані в електронній формі з Інтернет-ресурсів Botanicus (www.botanicus.org) i Biodiversity Heritage Library (www. biodiversitylibrary.org), а також у бібліотеці Міссурійського ботанічного саду (Peter H. Raven Library, Missouri Botanical Garden, St. Louis, Missouri, USA). При цьому виявилося, що насправді назва Crocus tauricus Steven ex Nyman (1882, Consp. Fl. Eur.: 706, pro syn.) була опублікована в синоніміці. Відповідно, на момент обнародування вона не була визнана автором публікації, а тому є невалідною і не має пріоритету над назвою $C$. tauricus (Trautv.) Puring.

У попередніх версіях World Checklist of Selected Plant Families (Royal Botanic Gardens, Kew, United Kingdom: http://apps.kew.org/wcsp) цей кримський вид наводився як синонім Crocus adamii J. Gay (1831, Bull. Sci. Nat. Géol. 25(Mem.): 319) або C. biflorus Mill. subsp. adamii (J. Gay) B. Mathew (1982, Crocus: 83), a назва Crocus tauricus Steven ex Nyman вважалася валідно опублікованим старшим (раніше опублікованим і тому пріоритетним) омонімом назви C. tauricus (Trautv.) Puring i розглядалася як синонім виду C. speciosus M. Bieb. У новій версії World Checklist... (станом на жовтень 2012 р.) ця помилка виправлена. Відповідно до цього C. tauricus (Trautv.) Puring тепер є визнаною назвою і може законно використовуватися в новому виданні «Червоної книги України».

\section{Родина Liliaceae Juss.}

Gagea serotina (L.) Ker Gawl., 1816, Quart. J. Roy. Inst. 1: 180.

- Bulbocodium serotinum L., 1753, Sp. Pl.: 294.

- Anthericum serotinum (L.) L., 1762, Sp. Pl. ed. 2: 444.

- Lloydia serotina (L.) Rchb., 1830, Fl. Germ. Excurs.: 102.

- Ornithogalum serotinum (L.) Rchb. in J.C. Mössler \& H.G.L. Reichenbach, 1833, Handb. Gewächsk. ed. 3, 1: 554 .
У «Червоній книзі України» цей вид наведено як Lloydia serotina. Європейські види Gagea та L. serotina (єдиний вид Lloydia, шо природно трапляється в Свропі) розрізняються досить чітко, тому може викликати подив, чому запропоновано об'єднати такі начебто різні роди. Проте в інших частинах ареалів видів цих родів ситуація не така однозначна, й різні автори переносили деякі види з одного роду до іншого (Greuter, 1970; Шерин, Шмаков, 2011; див. також огляди: Zarrei et al., 2009, 2011). Навіть до настання «молекулярно-філогенетичної ери» близька спорідненість цих двох родів не ставилася під сумнів. Молекулярно-філогенетичні дослідження спочатку підтвердили їхню філогенетичну близькість (Fay et al., 2006), а згодом (Peruzzi et al., 2008; Peterson et al., 2008; Zarrei et al., 2009) показали філогенетичну вкоріненість видів Lloydia в межах Gagea, щоправда, біля основи філогенетичного дерева Gagea s. 1.; до того ж, види Lloydia розподілилися по двох або трьох кладах. Таким чином, об’єднання двох родів під пріоритетною назвою Gagea є досить обгрунтованим. Водночас при перенесенні лише частини видів Lloydia до Gagea залишається можливість зберегти рід Lloydia як самостійний, але в дешо звуженому обсязі (Zarrei et al., 2011).

Слід згадати, що види цього родового комплексу неодноразово переводилися різними авторами 3 одного роду до іншого (як це, зокрема, видно навіть із досить неповної синоніміки Gagea serotina, наведеної вище), та й більшість «ліннеївських» видів Gagea спочатку вміщувалися К. Ліннеєм у рід Ornithogalum L., який тепер належить до родини Hyacinthaceae Batsch ex Borkh. s. str. (Asparagaceae Juss. s. 1.) порядку Asparagales Link (а не Liliales Perleb). Принагідно зазначимо, шо група Asparagales (= Iridales Raf.) у розумінні й обсязі, які прийняті Групою з філогенії покритонасінних (Angiosperm Phylogeny Group, APG) та в численних недавніх публікаціях на основі системи APG (APG, 1998, 2003, 2009; Chase, Reveal, 2009; Chase et al., 2009 та ін.), очевидно, потребує розділення на менші за обсягом порядки (див. Reveal, 2012).

\section{Magnoliophyta: Magnoliopsida}

Родина Asteraceae Bercht. \& J. Presl (Compositae Giseke)

Rhaponticoides taliewii (Kleopow) M.V. Agab. \& Greuter, 2003, Willdenowia 33(1): 61.

- Centaurea taliewii Kleopow, 1927, Изв. Киевск. бот. сада 5-6: 87. 
Зміни в номенклатурі цього виду, а також ще одного виду природної флори України Rhaponticoides ruthenica (Lam.) M.V. Agab. \& Greuter (2003, Willdenowia 33(1):61 = Centaurea ruthenica Lam.), пов'язані, з одного боку, з результатами молекулярно-філогенетичних досліджень, а з іншого - $з$ новою лектотипіфікацією роду Centaurea L. (Greuter et al., 2001), а точніше, з номенклатурною консервацією родової назви Centaurea із законсервованим типом $(C$. paniculata L., typ. cons.). Детальніше номенклатурно-таксономічна ситуація описана в цитованій роботі В. Гройтера (Greuter, 2003).

Зазначимо лише, що якби не нова лектотипіфікація, довелося б створювати нові номенклатурні комбінації для багатьох (очевидно, сотень) видів, а також внутрішньовидових і внутрішньородових таксонів, які традиційно відносили до Centaurea. Така ситуація склалася внаслідок того, що тепер можна вважати доведеним, що Centaurea s. 1. має бути розділеним на декілька природніших монофілетичних таксонів родового рангу (Susanna et al., 1995; Garcia-Jacas et al., 2000, 2001; Greuter, 2003; Susanna, Garcia-Jacas, 2007).

Точна кількість сегрегатних родів, які потрібно та доцільно виділяти, поки що лишається дискусійною, проте очевидно, що у флорі України слід визнавати, крім Centaurea s. str. (incl. Acosta Adans., Calcitrapa Adans., Chartolepis Cass., Cnicus L., Jacea Mill., можливо, також Carthamus L. та ін.), ще принаймні Rhaponticoides Vaill. і Psephellus Cass. у дещо зміненому обсязі (див. Wagenitz, Hellwig, 2000), а можливо, ще й Cyanus Mill. (хоча родовий статус останнього є дуже проблематичним). Можна лише радіти з того, що кількість сегрегатних родів у разі прийняття такої схеми є досить невеликою, а інші час від часу вживані у флористичній літературі родові назви (зокрема, Acosta, Calcitrapa, Jacea та ін.) не заслуговують на таксономічне визнання.

Родина Ericaceae Juss.

Kalmia L., 1753, Sp. Pl. 1: 391.

Kalmia procumbens (L.) Gift, Kron \& P.F. Stevens ex Galasso, Banfi \& F. Conti, 2005, Annot. Checkl. Italian Vasc. Fl.: 20.

- Kalmia procumbens (L.) Gift, Kron \& P.F. Stevens, 2002, Bot. Rev. 68(3): 409, nom. inval. (sine basion.).

- Kalmia procumbens (L.) Gift \& Kron, 2008, Nordic J. Bot. 26(1-2): 47, comb. superfl.

- Azalea procumbens L. 1753, Sp. Pl. 1: 151.

- Loiseleuria procumbens (L.) Loisel., 1812, Traité Arbr. Arbust. (Duhamel), nouv. éd. 5: 227. 1812.
- Loiseleuria procumbens (L.) Desv., 1813, J. Bot. Agric. 1: 35.

- Rhododendron procumbens (L.) Alph. Wood, 1845, Class-book Bot. (ed. 1): 236.

У «Червоній книзі України» цей вид наводиться під назвою Loiseleuria procumbens як єдиний представник монотипного роду Loiseleuria Desv. (1813, J. Bot. Agric. 1: 35, nom. cons. = Loiseleuria Desv. ex Loisel., 1812, Traité Arbr. Arbust. (Duhamel), nouv. éd. 5: 227). Як видно з наведеної синоніміки, вид має досить складну номенклатурну історію. Варто згадати, що до роду Kalmia його переносили тричі (див. Kron et al., 2008), причому двічі невдало: перший раз не вказали базіонім запропонованої номенклатурної комбінації, а другий створили зайву номенклатурну комбінацію.

У роді Kalmia (включаючи Kalmiella Small, Leiophyllum (Persoon) R. Hedwig, Loiseleuria) налічується близько 10 видів, поширених у материковій частині Північної Америки (8 видів) і на Кубі (один ендемічний вид $-K$. ericoides $\mathrm{C}$. Wright ex Griseb. = Kalmiella ericoides (C. Wright ex Griseb.) Small). Лише один вид, K. procumbens, не є ендемічним для північноамериканського континенту, а поширений також і на півночі Євразії та подекуди на півдні в гірських регіонах.

Kalmia procumbens i K. buxifolia (Bergius) Gift \& Kron (= Ledum buxifolium Bergius; Leiophyllum buxifolium (Bergius) Elliott) традиційно розглядалися у складі монотипних родів Loiseleuria та Leiophyllum, але їхнє включення до Kalmia підтверджується результатами молекулярно-філогенетичних досліджень (Kron, 1997; Kron, King, 1996; Kron et al., 2002; Gillespie, Kron, 2010 та ін.). П.Ф. Стівенс зі співавторами (Stevens et al., 2004) на основі морфологічних даних також включили Leiophyllum і Loiseleuria до Kalmia. У цих двох видів наявні віночки, глибоко розділені на майже вільні пелюстки, що не характерно для Kalmia; проте в усьому іншому ці рослини морфологічно не відокремлюються від решти представників Kalmia.

\section{Родина Lamiaceae Martinov (Labiatae Juss.)}

Clinopodium serpyllifolium (M. Bieb.) Kuntze, 1891, Revis. Gen. Pl. 2: 515.

- Nepeta serpyllifolia M. Bieb., 1808, Fl. Taur.Caucas. 2: 40.

- Micromeria serpyllifolia (M. Bieb.) Boiss., 1859, Diagn. Pl. Orient., ser. 2, 4: 13, nom. illeg., non Scheele, 1849. 
- Melissa serpyllifolia (M. Bieb.) Nyman, 1865, Syll. Fl. Eur., Suppl.: 20.

- Satureja serpyllifolia (M. Bieb.) Briq. in H.G.A. Engler \& K.A.E. Prantl, 1896, Nat. Pflanzenfam. 4(3a): 301.

- Micromeria fruticosa (L.) Kuntze subsp. serpyllifolia (M. Bieb.) P.H. Davis, 1951, Kew Bull. 6: 77.

У «Червоній книзі України» (2009) цей вид наведено під незаконною назвою Micromeria serpyllifolia (M. Bieb.) Boiss., яка є пізнішим омонімом назви M. serpyllifolia Scheele (1849, Linnaea 22: 593). Останній вид був описаний, імовірно, з території нинішньої Хорватії («Dalmatia») і тепер вважається синонімом виду $M$. croatica (Pers.) Schott (Bräuchler et al., 2008). Отже, використовувати назву M. serpyllifolia для включеного до «Червоної книги України» виду, який трапляється в Криму, надалі неможливо.

Як видно з наведеної вище синоніміки, пропонувалося розглядати наш таксон у ранзі підвиду виду Micromeria fruticosa (L.) Kuntze. Проте в роді Clinopodium неможливо використовувати ліннеївський епітет «fruticosum» (Clinopodium fruticosum (L.) Kuntze, Revis. Gen. Pl. 2: 516, nom. illeg.), який базується на Melissa fruticosa L. (1753, Sp. Pl. 2: 593), через наявність омоніму Clinopodium fruticosum Forssk. (1775, Fl. Aegypt. Arab.: 107).

Молекулярно-філогенетичні дослідження та детальний таксономічний аналіз (Bräuchler et al., 2005, 2008; Meimberg, Heubl, 2006) показали, що рід Micromeria Benth. у його традиційному обсязі $є$ поліфілетичноюгрупою. Зокрема, група Micromeria sect. Pseudomelissa Benth. виявилася філогенетично вкоріненою серед видів роду Clinopodium L. Саме до цієї групи й належить вид, який трапляється в Україні. Для всіх видів цієї секції, які ще не мали законних назв у роді Clinopodium, були зроблені відповідні номенклатурно-таксономічні комбінації (Bräuchler et al., 2008). Рід Micromeria і тепер є визнаним, але в дещо вужчому обсязі. Отже, правильною назвою для занесеного до «Червоної книги України» виду однозначно є Clinopodium serpyllifolium.

Phlomoides scythica (Klokov \& Des.-Shost.) Czer. 1995, Vasc. Pl. of Russia and Adjacent States: 296.

- Phlomis scythica Klokov \& Des.-Shost. 1938, Бот. матер. Герб. Бот. инст. АН СССР, 8: 31.

У «Червоній книзі України» (2009) вид наведено під назвою Phlomis scythica, а видова комбінація в роді Phlomoides вказана у синоніміці.
Рід Phlomoides Moench (1794, Methodus: 403) уперше був описаний у 1794 р., але після цього тривалий час не визнавався і синонімізувався з родом Phlomis L. Відновлення статусу роду для цієї групи пов'язане з працями Р.В. Камеліна зі співавторами (Адылов и др., 1986; Камелин, Махмедов, 1990). С.К. Черепанов (1. с.) визнав Phlomoides як рід і опублікував нову номенклатурну комбінацію в ранзі виду для таксона, котрий тепер включений до «Червоної книги України». Проте навіть після цього в багатьох українських таксономічних зведеннях види Phlomoides (у тому числі широко розповсюджений P. tuberosa (L.) Moench $=$ Phlomis tuberosa L.) розглядалися в межах збірного роду Phlomis.

Недавні молекулярно-філогенетичні й порівняльно-морфологічні дослідження (Ryding, 2008; Маthiesen et al., 2011; Salmaki et al., 2012 та ін.) достовірно підтвердили самостійність роду Phlomoides i обгрунтованість таксономічного висновку, до якого раніше дійшли Р.В. Камелін зі співавторами. Правильна назва занесеного до «Червоної книги України» (2009) таксона в ранзі виду наведена вище, проте слід зазначити, що в Україні М.В. Клоков та інші автори визнавали декілька дуже близьких видів зі спорідненості P. tuberosa, деякі з них ще не були переведені до роду Phlomoides. Рішення щодо їхнього видового або внутрішньовидового статусу потребує подальших досліджень.

\section{Родина Rosaceae Juss.}

Torminalis Medik., 1789, Philos. Bot. 1: 134.

Torminalis clusii M. Roem. ex K.R. Robertson \& J.B. Phipps, 1991, Syst. Bot. 16(2): 390.

- Crataegus torminalis L., 1753, Sp. Pl. 1: 476.

- Pyrus torminalis (L.) Ehrh., 1791, Beitr. Naturk. 6: 92.

- Sorbus torminalis (L.) Crantz, 1763, Stirp. Austr. Fasc. 2: 45.

- Torminaria clusii M. Roem., 1847, Syn. Rosifl.: 130, nom. illeg.

- Torminaria torminalis (L.) Dippel, 1893, Handb. Laubholzk. 3: 387.

- Torminaria vulgaris Schur, 1866, Enum. Pl. Transsilv.: 207, nom. illeg.

У «Червоній книзі України» (2009) вид вміщений під назвою Sorbus torminalis, а в синоніміці наведені назви Crataegus torminalis і Pyrus torminalis. 3 наведеної вище синоніміки видно, що берека має досить складну та заплутану номенклатурну історію. 
Як підтвердилося в результаті молекулярно-філогенетичних досліджень (і як вважали багато авторів задовго до таких досліджень - див. огляд у Aldasoro et al., 2004 та ін.), рід Sorbus L. у його традиційному широкому розумінні є поліфілетичним (Evans, Campbell, 2002; Potter et al., 2007 та ін.; див. також Stace, 2010).

Загалом перебіг еволюції у цій групі поки що надійно простежити досить складно. Молекулярнофілогенетичні реконструкції на основі аналізу нуклеотидних послідовностей ядерної та хлоропластної ДНК інколи суперечать одна одній і залишаються досить проблематичними, що, очевидно, зумовлено широкомасштабною давньою (та почасти й сучасною) гібридизацією представників групи, а також іншими еволюційно значущими та частково пов'язаними з гібридизацією феноменами, а саме поліплоїдією (переважно аллоплоїдією) та апоміксисом. Проте вже достовірно зрозуміло, що представники Sorbus (у традиційному розумінні) наявні принаймні в 4-5 окремих філогенетичних лініях (кладах), розкиданих від основи до верхівки ймовірного філогенетичного дерева, й «перемішані» поміж таких добре відомих і широко визнаних таксонів родового рангу, як Pyrus L., Malus Mill., Pyracantha M. Roem., Cydonia Mill., Photinia Lindl., Cotoneaster Medik., Chaenomeles Lindl., Aronia Medik. та ще декілька інших.

Адекватно відобразити таку ситуацію номенклатурно-таксономічними засобами (за умови збереження монофілетичного статусу таксонів, що виділяються) можна двома основними способами: або об'єднати все різноманіття цієї групи в межах одного роду (або небагатьох родів), або ж розділити «проблемний» рід Sorbus s. 1. на декілька сегрегатних монофілетичних родів, а саме: Sorbus sensu stricto (включаючи тип роду, S. aucuparia L.), Cormus Spach (Sorbus domestica L. = Cormus domestica (L.) Spach та ін.), Torminalis (див. вище), Aria (Pers.) Host (види зі спорідненості $S$. aria (L.) Crantz) і Chamaemespilus Medik. (Chamaemespilus alpina (Mill.) K.R. Robertson \& J.B. Phipps). У разі об’єднання групи в один рід він, найімовірніше, матиме назву Pyrus L. і включатиме всі згадані вище та деякі інші роди. Навряд чи таке рішення буде позитивно сприйняте як ботанічною спільнотою, так і тими, хто більш далекий від систематики, а особливо практиками сільського та лісового господарств, садівництва та зеленого будівництва тощо, які звикли до того, що груша, яблуня, горобина, айва та багато інших належать до окремих родів.
Очевидно, більш зручним і філогенетично обгрунтованим рішенням буде розділення Sorbus s.l. на декілька згаданих вище родів, тим більше що морфологічно вони досить добре відокремлені один від одного. Певні проблеми становитиме номенклатура міжродових гібридів, але в цій групі гібридизують між собою не лише представники Sorbus s. 1. (Stace, 2010). 3 точки зору сприйняття сегрегатних родів, слід сподіватися на поступове «звикання» до нової таксономічної схеми. Зрештою, звикли ж до того, що «чорноплідна горобина» насправді належить до окремого роду Aronia, а зовсім не до Sorbus.

До певної міри аналогічна таксономічна ситуація спостерігається й у філогенетичній групі, яка містить представників Prunus L. та багатьох інших родів із цієї спорідненості (Padus Mill., Cerasus Mill., Laurocerasus Duhamel, Persica Mill., Amygdalus L., Armeniaca Mill. тощо), але домінуюче рішення тут прямо протилежне: західноєвропейські та американські ботаніки зараз переважно схиляються до визнання Prunus sensu lato (Potter et al., 2007 та ін.), проте східноєвропейські та деякі азійські ботаніки надають перевагу визнанню численних сегрегатних родів.

Зважаючи на доведену значну філогенетичну відокремленість Torminalis від Sorbus, у новому виданні «Червоної книги України» слід визнати назву Torminalis clusii замість Sorbus torminalis.

Отже, принаймні вісім видів судинних рослин, занесених до третього видання «Червоної книги України» (2009), безперечно, з номенклатурних і таксономічних причин мають бути наведені в новому виданні під іншими назвами. Ці назви повинні також використовуватися у сучасній ботанічній і природоохоронній літературі та документації, в разі необхідності з наведенням синонімічних назв, під якими ці види відомі в нині діючому офіційному виданні. Інші номенклатурно-таксономічні зміни, найімовірніше, охоплять ще низку видів і будуть висвітлені в наступних публікаціях, але в кожному конкретному випадку рекомендувати такі зміни слід лише після детального та виваженого аналізу їхніх причин і аргументації фахівців-систематиків.

\section{СПИСОК ЛІТЕРАТУРИ}

1. Адылов Т.А., Камелин Р.В., Махмедов А.М. Заметки о семействе Lamiaceae, 1 // Новости сист. высш. растений. Л.: Наука, 1986. - Т. 23. - С. 110-115.

2. Камелин P.B., Махмедов A.M. Система рода Phlomoides (Lamiaceae) // Ботан. журн. - 1990. - 75, № 2. - С. 241250 .

ISSN 0372-4123. Ukr. Botan. Journ., 2013, vol. 70, № 2 
3. Мосякін С.Л., Тищенко О.В. Прагматична філогенетична класифікація спорових судинних рослин флори України // Укр. ботан. журн. - 2010. - 67, № 6. - С. 802-817.

4. Червона книга Украӥни. Рослинний світ / Під заг. ред. Я.П. Дідуха. - Київ: Глобалконсалтинг, 2009. - 912 с.

5. Шерин И.А., Шмаков А.И. Конспект видов рода Gagea Salisb. Алтайской горной страны // Изв. Алтайского гос. ун-та. - 2011. - Вып. 3-2 (71). - С. 69-73.

6. Шмаков А.И. Конспект папоротников России // Turczaninowia. - 2001. - 4, №1-2. - С. 36-72.

7. Цвелев Н.Н. Краткий конспект сосудистых споровых растений Восточной Европы // Новости сист. высш. растений. - СПб: Изд-во БИН им. В.Л. Комарова, 2005. 32. - C. 7-32.

8. Aldasoro J.J., Aedo C., Muñoz Garmendia F., Pando de la Hoz F., Navarro C. Revision of Sorbus subgenera Aria and Torminaria (Rosaceae-Maloideae) // Syst. Bot. Monographs. - 2004. 69. - P. $1-148$.

9. $A P G$ (Angiosperm Phylogeny Group). An ordinal classification for the families of flowering plants // Ann. Missouri Bot. Gard. - 1998. - 85. - P. 531-553.

10. APG II (Angiosperm Phylogeny Group). An update of the Angiosperm Phylogeny Group classification for the orders and families of flowering plants: APG II // Bot. J. Linnean Soc. - 2003. - 141. - P. 399-436.

11. APG III (Angiosperm Phylogeny Group). An update of the Angiosperm Phylogeny Group classification for the orders and families of flowering plants: APG III // Bot. J. Linnean Soc. - 2009. - 161. - P. 105-121.

12. Bräuchler C., Meimberg H., Abele T., Heubl G. Polyphyly of the genus Micromeria Benth. (Lamiaceae): evidence from cpDNA sequence data // Taxon. - 2005. - 54. - P. 639-650.

13. Bräuchler C., Ryding O., Heubl G. The genus Micromeria (Lamiaceae), a synoptical update // Willdenowia. - 2008. 38. - P. 363-410.

14. Brown R. Prodromus Florae Novae Hollandiae et Insulae VanDiemen. - London: Typis Richardi Taylor et socii [Richard Taylor \& Sons], 1810. - Vol. 1. - viii + 145-592 p.

15. Chase M.W., Reveal J.L. A phylogenetic classification of the land plants to accompany APG III // Bot. J. Linnean Soc. 2009. - 161. - P. 122-127.

16. Chase M.W., Reveal J.L., Fay M.F. A subfamilial classification for the expanded asparagalean families Amaryllidaceae, Asparagaceae and Xanthorrhoeaceae // Bot. J. Linnean Soc. 2009. - 161. - P. 132-136.

17. Christenhusz M.J.M., Zhang Xian-Chun, Schneider H. A linear sequence of extant families and genera of lycophytes and ferns // Phytotaxa. - 2011. - 19. - P. 7-54.

18. Evans R.C., Campbell C.S. The origin of the apple subfamily (Maloideae; Rosaceae) is clarified by DNA sequence data from duplicated GBSSI genes // Amer. J. Bot. - 2002. - 89. P. $1478-1484$.

19. Fay M.F., Chase M.W., Rønsted N., Devey D.S., Pillon Y., Pires J.C., Petersen G., Seberg O., Davis J.I. Phylogenetics of $L i$ liales: summarized evidence from combined analyses of five plastid and one mitochondrial loci // Aliso. - 2006. - 22. P. 559-565.

20. Fraser-Jenkins C.R., Dulawat C.S. A summary of Indian cheilanthoid ferns and the discovery of Negripteris (Pteridaceae), an Afro-Arabian fern genus new to India // Fern Gaz. 2009. - 18. - P. 216-229.
21. Garcia-Barriuso M., Bernardos S., Nabais C., Pereira D., Amich F. Phytogeochemical, geographical and vulnerability study of the Paleosubtropical element Notholaena marantae subsp. marantae (Sinopteridaceae) at the western edge of its range // Biologia, Sect. Bot. - 2011. - 66. - P. 258-265.

22. Garcia-Jacas N., Susanna A., Mozaffarian R., Ilarslan R. The natural delimitation of Centaurea (Asteraceae: Cardueae): ITS sequence analysis of the Centaurea jacea group // Pl. Syst. Evol. - 2000. - 223. - P. 185-199.

23. Garcia-Jacas N., Susanna A., Garnatje T., Vilatersana R. Generic delimitation and phylogeny of the subtribe Centaureinae (Asteraceae): a combined nuclear and chloroplast DNA analysis // Ann. Bot. - 2001. - 87. - P. 503-515.

24. Gastony G.J., Rollo D.R. Phylogeny and generic circumscriptions of cheilanthoid ferns (Pteridaceae: Cheilanthoideae) inferred from $r b c L$ nucleotide sequences // Amer. Fern J. 1995. - 85. - P. 341-360.

25. Gillespie E., Kron K. Molecular phylogenetic relationships and a revised classification of the subfamily Ericoideae (Ericaceae) // Mol. Phylog. Evol. - 2010. - 56. - P. 343-354.

26. Greuter $W$. The taxonomic position of Lloydia graeca (Liliaceae) and related species // Israel J. Bot. - 1970. - 19. P. $155-160$.

27. Greuter $W$. The Euro+Med treatment of Cardueae (Compositae) - generic concepts and required new names // Willdenowia. - 2003. - 33. - P. 49-61.

28. Greuter W., Wagenitz G., Agababian M., Hellwig F. Proposal to conserve the name Centaurea (Compositae) with a conserved type // Taxon. - 2001. - 50. - P. 1201-1205.

29. Kron K.A. Phylogenetic relationships of Rhododendroideae (Ericaceae) // Amer. J. Bot. - 1997. - 84. - P. 973-980.

30. Kron K.A., Judd W.S., Anderberg A.A. Validation of Kalmia buxifolia (Bergius) Gift \& Kron and Kalmia procumbens (L.) Gift \& Kron // Nordic J. Bot. - 2008. - 26. - P. 47-48.

31. Kron K.A., Judd W.S., Stevens P.F., Crayn D.M., Anderberg A.A., Gadek P.A., Quinn C.J., Luteyn J.L. Phylogenetic classification of Ericaceae: Molecular and morphological evidence // Bot. Rev. - 2002. - 68. - P. 335-423.

32. Kron K.A., King J.M. Cladistic relationships of Kalmia, Leiophyllum, and Loiseleuria (Phyllodoceae, Ericaceae) based on rbcL and nrITS data // Syst. Bot. - 1996. - 21. - P. 17-29.

33. Manning J., Forest F., Vinnersten A. The genus Colchicum L. redefined to include Androcymbium Willd. based on molecular evidence // Taxon. - 2007. - 56. - P. 872-882.

34. Mathiesen C., Scheen A.-C., Lindqvist $C$. Phylogeny and biogeography of the lamioid genus Phlomis (Lamiaceae) // Kew Bulletin. - 2011. - 66. - P. 83-99.

35. Meimberg H., Heubl G. New names in Old World Clinopodium - the transfer of the species of Micromeria sect. Pseudomelissa to Clinopodium // Taxon. - 2006. - 55. - P. 977-981.

36. Mosyakin S.L., Fedoronchuk M.M. Vascular plants of Ukraine: A nomenclatural checklist. - Kiev, 1999. - xxiv + 346 p.

37. Persson K. Nomenclatural synopsis of the genus Colchicum (Colchicaceae), with some new species and combinations // Botanische Jahrbücher für Systematik, Pflanzengeschichte und Pflanzengeographie (Bot. Jahrb. Syst.). - 2007. - 127. P. $165-242$.

38. Persson K., Petersen G., del Hoyo A., Seberg O., Jørgensen T. A phylogenetic analysis of the genus Colchicum L. (Colchicaceae) based on sequences from six plastid regions // Taxon. - 2011. - 60. - P. 1349-1365. 
39. Peruzzi L., Peterson A., Tison J.-M., Peterson J. Phylogenetic relationships of Gagea Salisb. (Liliaceae) in Italy, inferred from molecular and morphological data matrices // Pl. Syst. Evol. - 2008. - 276. - P. 219-234.

40. Peterson A., Levichev I.G., Peterson J. Systematics of Gagea and Lloydia (Liliaceae) and infrageneric classification of Gagea based on molecular and morphological data // Mol. Phylog. Evol. - 2008. - 46. - P. 446-465.

41. Pichi Sermolli R.E.G. Again on the typification of the generic name Notholaena R. Brown //Webbia. - 1989. - 43. - P. 301310.

42. Potter D., Eriksson T., Evans R.C., Oh S., Smedmark J.E.E., Morgan D.R., Kerr M., Robertson K.R., Arsenault M., Dickinson T.A., Campbell C.S. Phylogeny and classification of the Rosaceae // Pl. Syst. Evol. - 2007. - 266. - P. 5-43.

43. Reveal J.L. An outline of a classification scheme for extant flowering plants // Phytoneuron. - 2012. - 37. - P. 1-221.

44. Rothfels C.J., Windham M.D., Grusz A.L., Gastony G.J., Pryer K.M. Toward a monophyletic Notholaena (Pteridaceae): resolving patterns of evolutionary convergence in xeric-adapted ferns // Taxon. - 2008. - 57. - P. 712-724.

45. Ryding $O$. Pericarp structure and phylogeny of the Phlomis group (Lamiaceae subfam. Lamioideae) // Bot. Jahrb. Syst. 2008. - 127. - P. 299-316.

46. Salmaki Y., Zarre S., Ryding O., Lindqvist C., Scheunert A., Bräuchler C., Heubl G. Phylogeny of the tribe Phlomideae (Lamioideae: Lamiaceae) with special focus on Eremostachys and Phlomoides: New insights from nuclear and chloroplast sequences // Taxon. - 2012. - 61. - P. 161-179.

47. Smith A.R., Pryer K.M., Schuettpelz E., Korall P., Schneider H., Wolf P.G. A classification for extant ferns // Taxon. - 2006. 55. - P. 705-731.

48. Stace C.A. Classification by molecules: What's in it for field botanists? // Watsonia. - 2010. - 28. - P. 103-122.

49. Stevens P.F., Luteyn J.L., Oliver E.G.H., Bell T.L., Brown E.A., Crowden R.K., George A.S., Jordan G.J., Ladd P., Lemson K., McLean C.B., Menadue Y., Pate J.S., Stace H.M., Weiller C.M. Ericaceae // Kubitzki K. (ed.). The families and genera of vascular plants. - Berlin: Springer-Verlag, 2004. - Vol. 6. Flowering Plants. Dicotyledons: Celastrales, Oxalidales, Rosales, Cornales, Ericales. - P. 145-194.

50. Susanna A., Garcia-Jacas N. Compositae: Tribe Cardueae // Kubitzki K. (ed.). The families and genera of vascular plants. Berlin; Heidelberg: Springer-Verlag, 2007. - Vol. 8. Flowering Plants. Eudicots: Asterales / Volume eds. J.W. Kadereit and C. Jeffrey. - P. 123-146.

51. Susanna A., Garcia-Jacas N., Soltis D.E., Soltis P.S. Phylogenetic relationships in tribe Cardueae (Asteraceae) based on ITS sequences // Amer. J. Bot. - 1995. - 82 - - P. 1056-1068.

52. Vinnersten A., Manning J. A new classification of Colchicaceae // Taxon. - 2007. - 56. - P. 163-169.

53. Vinnersten A., Reeves $G$. Phylogenetic relationships within $\mathrm{Col}$ chicaceae // Amer. J. Bot. - 2003. - 90. - P. 1455-1462.

54. Vorontsova M.S., Simon B.K. Updating classifications to reflect monophyly: 10 to 20 percent of species names change in Poaceae // Taxon. - 2012. - 61. - P. 735-746.

55. Wagenitz G., Hellwig F.H. The genus Psephellus Cass. (Compositae, Cardueae) revised with a broadened concept // Willdenowia. - 2000. - 30. - P. 29-44.

56. Windham M.D. Notholaena // Flora of North America north of Mexico / Ed. by Flora of North American Editorial Com- mittee. - New York: Oxford Univ. Press, 1993. - Vol. 1. - P. 143-149.

57. Windham M.D., Huiet L., Schuettpelz E., Grusz A.L., Rothfels C., Beck J., Yatskievych G., Pryer K.M. Using plastid and nuclear DNA sequences to redraw generic boundaries and demystify species complexes in cheilanthoid ferns // Amer. Fern J. 2009. - 99. - P. 128-132.

58. Yatskievych G., Smith A.R. Typification of Notholaena R. Br. (Pteridaceae) // Taxon. - 2003. - 52. - P. 331-336.

59. Zarrei M., Wilkin P., Fay M.F., Ingrouille M.J., Zarre S., Chase M.W. Molecular systematics of Gagea and Lloydia ( $\mathrm{Li}$ liaceae; Liliales): implications of analyses of nuclear ribosomal and plastid DNA sequences for infrageneric classification // Ann. Bot. - 2009. - 104. - P. 125-142.

60. Zarrei M., Wilkin P., Ingrouille M.J., Chase M.W. A revised infrageneric classification for Gagea Salisb. (Tulipeae; Liliaceae): insights from DNA sequence and morphological data // Phytotaxa. - 2011. - 15. - P. 44-56.

Рекомендує до друку

Надійшла 05.11.2012 p.

Я.П. Дідух

\section{С.Л. Мосякин}

Институт ботаники имени Н.Г. Холодного НАН Украины, г. Киев

\section{НОМЕНКЛАТУРНО-ТАКСОНОМИЧЕСКИЕ ИЗМЕНЕНИЯ, КАСАЮЩИЕСЯ НЕКОТОРЫХ ВИДОВ СОСУДИСТЫХ РАСТЕНИЙ, ЗАНЕСЕННЫХ В «КРАСНУЮ КНИГУ УКРАИНЫ»}

Современный таксономический статус и номенклатура девяти таксономически проблемных видов сосудистых растений, занесенных в третье издание «Красной книги Украины», проанализированы на основе недавно вышедшей в свет филогенетической и таксономической литературы и других источников информации. Показано, что для некоторых видов таксономические и номенклатурные изменения являются неизбежными и в новом издании «Красной книги Украины» должны быть приняты новые названия. Приводятся номенклатурные цитаты и ссылки на литературу, а также обсуждения и обоснования для изменения названий видов растений. Перечисленные названия принимаются и детально обсуждаются: Paragymnopteris marantae (L.) K.H. Shing (= Notholaena marantae (L.) Desv.), Colchicum versicolor Ker. Gawl. (= Bulbocodium versicolor (Ker. Gawl.) Spreng.), Gagea serotina (L.) Ker Gawl. (= Lloydia serotina (L.) Rchb.), Rhaponticoides taliewii (Kleopow) M.V. Agab. \& Greuter (= Centaurea taliewii Kleopow), Kalmia procumbens (L.) Gift, Kron \& P.F. Stevens ex Galasso, Banfi \& F. Conti (= Loiseleuria procumbens (L.) Desv.), Clinopodium serpyllifolium (M. Bieb.) Kuntze (= Micromeria serpyllifolia M. Bieb. Boiss.), Phlomoides scythica (Klokov \& Des.-Shost.) Czer. (= Phlomis scythica Klokov \& Des.-Shost.), Torminalis clusii M. Roem. ex K.R. Robertson \& J.B. Phipps (= Sorbus torminalis (L.) Crantz). Подтверждена законность названия Crocus tauricus (Trautv.) Puring.

Ключ е в ы е сло в а: таксономия, номенклатура, сосудистые растения, Красная книга Украины, Paragymnopteris, Colchicum, Crocus, Gagea, Rhaponticoides, Kalmia, Clinopodium, Phlomoides, Torminalis. 


\section{S.L. Mosyakin}

M.G. Kholodny Institute of Botany, National Academy

of Sciences of Ukraine, Kyiv

\section{NOMENCLATURAL AND TAXONOMIC CHANGES AFFECTING THE NAMES \\ OF SOME VASCULAR PLANTS LISTED \\ IN THE RED DATA BOOK OF UKRAINE}

The current taxonomic status and nomenclature of nine taxonomically problematic species of vascular plants listed in the $3^{\text {rd }}$ edition of the Red Data Book of Ukraine are analyzed based on recent phylogenetic and taxonomic literature and other relevant evidence. For some species, taxonomic and nomenclatural changes are unavoidable and new names should be accepted in the new edition of the Red Data Book of Ukraine. Nomenclatural citations and literature references are provided, as well as discussion and justification for the name changes. The following names are ac- cepted and discussed in detail: Paragymnopteris marantae (L.) K.H. Shing (= Notholaena marantae (L.) Desv.), Colchicum versicolor Ker. Gawl. (= Bulbocodium versicolor (Ker. Gawl.) Spreng.), Gagea serotina (L.) Ker Gawl. (= Lloydia serotina (L.) Rchb.), Rhaponticoides taliewii (Kleopow) M.V. Agab. \& Greuter (=Centaurea taliewii Kleopow), Kalmia procumbens (L.) Gift, Kron \& P.F. Stevens ex Galasso, Banfi \& F. Conti (= Loiseleuria procumbens (L.) Desv.), Clinopodium serpyllifolium (M. Bieb.) Kuntze (= Micromeria serpyllifolia (M. Bieb.) Boiss.), Phlomoides scythica (Klokov \& Des.-Shost.) Czer. (= Phlomis scythica Klokov \& Des.-Shost.), and Torminalis clusii M. Roem. ex K.R. Robertson \& J.B. Phipps (= Sorbus torminalis (L.) Crantz). The validity of the name Crocus tauricus (Trautv.) Puring is confirmed.

K e y w o rds: taxonomy, nomenclature, vascular plants, Red Data Book of Ukraine, Paragymnopteris, Colchicum, Crocus, Gagea, Rhaponticoides, Kalmia, Clinopodium, Phlomoides, Torminalis.

\section{НОВІ ВИДАННЯ}

Конспект флоры Восточной Европы / Ред. Н.Н. Цвелев; ред. тома Д.В. Гельтман. - Ботанический институт им. В.Л. Комарова РАН. - Санкт-Петербург - Москва: Товарищество научных изданий «КМК», 2012. T. $1 .-630 \mathrm{c}$.

«Конспект флоры Восточной Европы» представляет собой полный перечень сосудистых растений этой территории. Составлен на основе «Флоры Восточной Европы» (1974-2004), начатой как «Флора европейской части СССР» с учетом накопившихся изменений и дополнений. Включает все естественно произрастающие и заносные, а также важнейшие культивируемые растения.

Книга рассчитана на ботаников, экологов, географов, работников системы охраны природы, преподавателей, аспирантов и студентов биологических вузов. 